\title{
( 181$)$
}

XV. Description of a new species of Chernetidx (Pseudoscorpionidæ) from Spain. By Chas. O. Waterhouse.

[Read Feb. 6th, 1878.]

At the May Meeting of the Entomological Society Mr. Grut exhibited a large species of Chelifer which he had received from Mr. Sydney Klein, who had taken the specimen in North Spain, in the crevices of rocks by the sea shore.

As the species appears to be undoubtedly new, I have thought well to describe it.

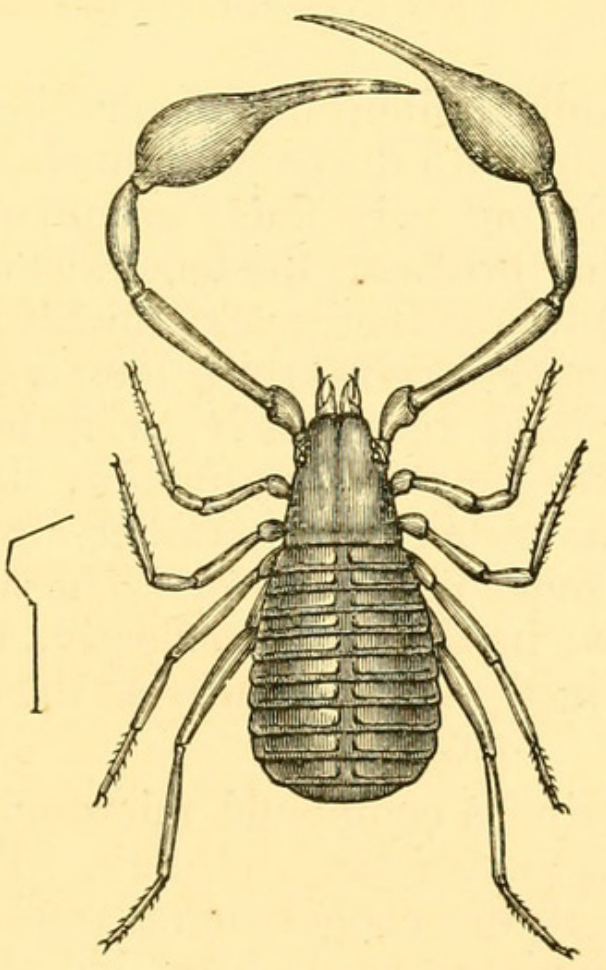

I sent a drawing of the specimen to Dr. Ludwig Koch, who has recently published a monograph of the Chernetida, and he pronounces it to be distinct from his Garypus litoralis, the only species to which I thought it could possibly be referred.

Dr. Koch throws some doubt on the species belonging to the genus Garypus, because it has not the cephalo-

TRANS. ENT. SOC. 1878, - PART II. (JULY.) 
thorax so much produced anteriorly as in the species produced by him. I think, however, that it would be unadvisable to propose a new genus for it on such slight grounds, and I, therefore, place it for the present in that genus.

I propose to name it-

\section{Garypus saxicola.}

Total length 7 millm., total length of palpus 11 millm.

The whole of the upper side is ashy-grey, the divisions between the abdominal segments and the whole underside are much paler, approaching to white; the palpi are rather darker than the upper surface of the body, and are tinged with greyish-purple, the apical joint rather more brown; the legs are pale testaceous.

The cephalothorax is broadest behind, narrowed in front, with a scarcely-perceptible mesial longitudinal impression in front. Two eyes on each side, placed on a slight swelling.

Mandibles shining, pitchy-testaceous, beset with a few long bristles. Palpi with the coxal joint short pear-shaped, testaceous, thickly but very finely granular, beset with a few very short fine bristles; the femoral and tibial joints a little enlarged towards their apex, thickly and very finely granular, the former very nearly $\frac{1}{3}$ longer than the tibial joint; the last joint very nearly twice as long as the femoral joint, extremely finely granular, the finger about $\frac{1}{4}$ longer than the swollen part, rather strongly granular and beset with some fine bristles. The abdominal segments are divided in the middle, closely, finely, but distinctly granular in the same manner as the cephalothorax.

\section{Hab.-Spain. Brit. Mus.}

I have been using a compound microscope, with a low power ( $1 \frac{1}{2}$ inch), to give the sculpture. With this glass the granulation of the cephalothorax and abdomen and fingers of the palpi are easily seen, but the sculpture of the femoral and tibial joints of the palpi is only seen by looking very carefully.

The specimen from which I have taken my description lived until September last; it caught house-flies which I placed in the box with it, and I noticed that the flies died very quickly when only held even by one pair of claws fixed in the thorax. 


\section{$2 \mathrm{BHL}$ Biodiversity Heritage Library}

Waterhouse, Charles Owen. 1878. "XV. Description of a new species of Chernetidæ (Pseudoscorpionidæ) from Spain." Transactions of the Entomological Society of London 26, 181-182. https://doi.org/10.1111/j.1365-2311.1878.tb00874.x.

View This Item Online: https://www.biodiversitylibrary.org/item/45285 DOI: https://doi.org/10.1111/j.1365-2311.1878.tb00874.x

Permalink: https://www.biodiversitylibrary.org/partpdf/20351

\section{Holding Institution}

Smithsonian Libraries

\section{Sponsored by}

Smithsonian

\section{Copyright \& Reuse}

Copyright Status: NOT_IN_COPYRIGHT

This document was created from content at the Biodiversity Heritage Library, the world's largest open access digital library for biodiversity literature and archives. Visit BHL at https://www.biodiversitylibrary.org. 